\title{
Assessment of the water quality in a large reservoir in semiarid region of Brazil ${ }^{1}$
}

\author{
Fernando B. Lopes ${ }^{2}$, Eunice M. de Andrade ${ }^{3}$, Ana C. M. Meireles ${ }^{4}$, Helena Becker ${ }^{5}$ \& Adriana A. Batista ${ }^{6}$ \\ ${ }^{1}$ Parte da Tese do primeiro autor \\ 2 DENA/CCA/UFC. Fortaleza, CE. Fone: (85) 3366-9762. E-mail: lopesfb@yahoo.com.br (Autor correspondente) \\ ${ }^{3}$ DENA/CCA/UFC. Fortaleza, CE. E-mail: eandrade@ufc.br \\ ${ }^{4}$ DENA/CCA/UFC. Fortaleza, CE. E-mail: ameireles2003@yahoo.com.br \\ ${ }^{5}$ DQAFQ/CC/UFC. Fortaleza, CE. Fone: (85) 3366-9964. E-mail: becker@ufc.br \\ ${ }^{6}$ DCAT/UFERSA. Mossoró, RN. E-mail: adrianaabtid2009@yahoo.com.br
}

Key words:

water quality

water pollution

multivariate statistics

\begin{abstract}
A B S T R A C T
The aim of this study was to identify spatial and temporal variations in water quality of Orós reservoir, Ceará, Brazil, as well as the sources of contamination. To get this information the Principal Component Analysis (PCA) and Cluster Analysis (CA) was used. Water samples were collected at seven (geo-referenced) points, from April 2008 to March 2011, totalling 4,032 samples. The following attributes of the waters were analysed: temperature, $\mathrm{pH}, \mathrm{CE}, \mathrm{Ca}^{2+}, \mathrm{Mg}^{2+}$, $\mathrm{Na}^{+}, \mathrm{K}^{+}, \mathrm{Cl}^{-}, \mathrm{HCO}_{3}^{-}, \mathrm{SO}_{4}^{--}$, turbidity, colour, Sechi transparency, TS, TVS, TFS, TSS, VSS, FSS, TDS, DO, $\mathrm{BO}_{5 \mathrm{D}}$, total phosphorus, soluble orthophosphate, EC, TTC, total ammonia, TKN, nitrate, SAR and chlorophyll-a. The PCA promoted the reduction from the 32 initial variables to 14 , accounting for $84.39 \%$ of the total variance. The major factors responsible for water quality composition are: the natural weathering of geological soil components; the entrainment of suspended solids through surface runoff from agricultural areas; and anthropogenic action in the Upper Jaguaribe basin in Ceará. The similarity of the water of the Orós reservoir allows a reduction in the number of sampling points, which may result in significant cost savings without sacrificing the water quality monitoring. The similarity of the waters was influenced by anthropic activities being carried out near the reservoir and all along the watershed.
\end{abstract}

Palavras-chave: qualidade da água poluição hídrica estatística multivariada

\section{Investigação da qualidade das águas de um grande reservatório na região semiárida do Brasil}

\begin{abstract}
R E S U M O
Objetivou-se estudar, com esta pesquisa, a variabilidade espaço temporal da qualidade das águas do açude Orós, Ceará, além das variáveis determinantes desta qualidade razão pela qual foram empregadas a análise de componentes principais (ACP) e a análise de agrupamento hierárquico (AAH). As amostras de água foram coletadas em sete pontos (georreferenciados), no período de abril de 2008 a março de 2011, totalizando 4032 amostras. Nas águas foram analisados os seguintes atributos: temperatura, $\mathrm{pH}, \mathrm{CE}, \mathrm{Ca}^{2+}, \mathrm{Mg}^{2+}, \mathrm{Na}^{+}, \mathrm{K}^{+}, \mathrm{Cl}^{-}, \mathrm{HCO}_{3}^{-}, \mathrm{SO}_{4}^{-}$, turbidez, cor, transparência de sechi, ST, STV, STF, SST, SSV, SSF, SDT, OD, $\mathrm{DBO}_{5}$, fósforo total, ortofosfato solúvel, EC, CTT, amônia total, NKT, nitrato, RAS e clorofila-a. A ACP promoveu redução das 32 variáveis iniciais para 14 variáveis explicando $84,39 \%$ da variância total. Os principais fatores responsáveis pela qualidade das águas do Orós foram: processo natural de intemperismo dos componentes geológicos do solo; carreamentos dos sólidos suspensos através do escoamento superficial das águas oriundas de áreas agrícolas e ações humanas ocorridas nas partes altas da bacia do Alto Jaguaribe. A similaridade das águas do Orós permite uma redução nos pontos de amostragem, o que pode resultar em menor custo sem comprometer o monitoramento da qualidade das águas. A similaridade das águas foi influenciada pelas atividades antrópicas exercidas nas proximidades do reservatório e ao longo da bacia.
\end{abstract}

\section{INTRODUCTION}

Water is the most important substance in nature, because the existence of all known life forms depends on it. According to UNESCO (2012), it is estimated that the world's urban population will increase from 3.4 to 6.3 billion people in the period from 2009 to 2050 . As the demand for water resources in the world increases, the likelihood of providing fresh water decreases. As an aggravating factor, in recent decades water quality has been deteriorating rapidly, which prevents the use of important reservoirs (Alexandre et al., 2010; Palácio et al.; 2011, Li et al., 2011; Guedes et al., 2012). These studies demonstrate the tendency of water resources to become ever scarcer, both quantitatively and qualitatively, should no clear action be taken which is aimed at improving the management of the supply and demand of water for different uses. Therefore, maintaining the water supply, not only in quantity but also in quality, is the biggest challenge to be overcome by society. 
In semiarid regions at low latitudes, dams and the artificial year-round use of rivers make up the main source of water for domestic, industrial and agricultural consumption (Andrade et al., 2007). As an important tool in the management of water resources, the assessment of water quality, should include the monitoring of trends which evolve both spatially and over time, thus enabling the identification of those anthropic and natural factors which determine the quality of surface waters (BrodnjakVoncina et al., 2002; Andrade et al., 2007; Bouza-Deaño et al., 2008; Li et al., 2011), in an effort to support environmental control measures (Guedes et al., 2012). The evaluation of water quality, as well as its spatial and temporal evolution, will only be possible through the implementation of systematic monitoring programs, resulting in a series of historical data that in the future can be analyzed in order to establish standards for seasonal and spatial distribution.

It therefore becomes necessary to use tools which allow the reduction and grouping of the large amount of information (historical data) arising from studies of the varying quality and quantity of water resources, involving a multivariate function of several aspects in such a way as to allow the interpretation and recognition of trends over time and in space (Alexandre et al., 2010; Li et al., 2011; Zhang et al., 2011).

Multivariate statistics along with Principal Component Analysis (PCA) and Cluster Analysis (CA) have been widely used in data from the monitoring of water quality (Singh et al., 2004; Andrade et al., 2008; Fernandes et al., 2010; Tanriverdi \& Demirkiran, 2010; Guedes et al., 2012). This type of analysis reduces the observational data and allows the interpretation of various components individually, since it can indicate associations between samples and/or variables, and also allows identification of possible factors and sources which influence the water system (Bouza-Deaño et al., 2008; Palácio et al., 2011; Guedes et al., 2012; Varol et al., 2012).

The aim of this research was to identify spatial and temporal variations in water quality of Orós reservoir, Ceará, Brazil, as well as the sources of contamination.

\section{MATERIAl AND Methods}

The area under study corresponds to the Orós reservoir, the main reservoir of the Upper Jaguaribe watershed, in the south of the State of Ceará (Figure 1). The dam of the reservoir was designed and completed in 1961 by Departamento Nacional de Obras Contra as Secas - DNOCS, for the purpose of allowing year-round usage of the Jaguaribe river, with a view to supplying the population (of the regions around Jaguaribe and metropolitan Fortaleza, the capital of Ceará), to developing irrigated agriculture, fish farming and tourism. The Orós reservoir (Figure 1) has a storage capacity at a bleed rate of 1.9 billion $\mathrm{m}^{3}$ of water and a surface area of approximately $190 \mathrm{~km}^{2}$.

According to the Köppen classification, the region presents a type BSw'h' hot semiarid climate with maximum rainfall in the autumn, and average monthly temperatures consistently above $18{ }^{\circ} \mathrm{C}$, with average annual rainfall (1974 to 2011) of $998 \pm 321$
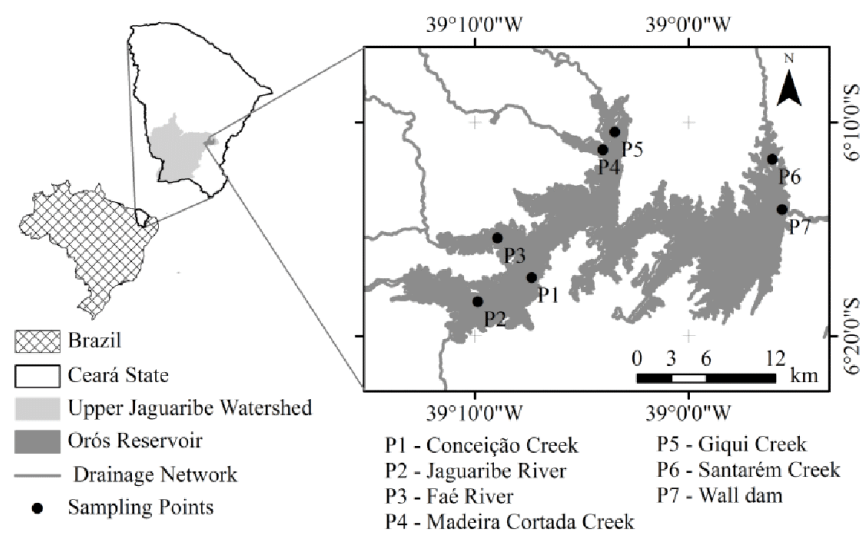

Figure 1. Location of the Orós reservoir, Ceará and sampling points

$\mathrm{mm}$, and rainfall in the region being mainly concentrated in the months of January to May, with the highest values recorded in March; evaporation, measured with a Class A evaporation tank, is around $1,988 \mathrm{~mm}$ year $^{-1}$, the relative humidity $66.1 \%$, with wind speeds of $1.8 \mathrm{~m} \mathrm{~s}^{-1}$ and sunshine of 2,945 hr year-1 (Andrade et al., 2008). The watershed of the Upper Jaguaribe features seven classes of soil: Argisols, Oxisols, Luvisols, Vertisols, Entisols, Alfisols and Planosols. Neosols together with Argisols are seen to be prevalent in the area taking up respectively 31.9 and $29.06 \%$ of the watershed. The absolute population resident in the catchment area of the Upper Jaguaribe watershed is approximately 600,000 inhabitants. As regards basic sanitation in the cities that make up the watershed, on average $85.95 \%$ of the households in the cities have a water supply, whereas sewage disposal is very precarious, only $11.22 \%$ of households being connected to the sewage system (IPECE, 2010).

The Upper Jaguaribe river basin is known historically for the importance of cotton in the region. Rice is the main feature of present-day agriculture. The cultivation of cotton has been reintroduced, but on a far smaller scale than in the past, along with crops of beans, cassava, maize and bananas, the latter being grown on a commercial basis. Also livestock farming is an important activity, where dairy, beef and poultry farming are highlighted (Ferreira et al., 2006). According to the COGERH (2011), $18.51 \%$ of the total catchment area is anthropic, $1.24 \%$ has exposed soil and $7.25 \%$ is made up of agricultural areas.

Water samples were collected at seven places (Figure 1), six representing the entry points of tributaries of the reservoir, and one upstream of the dam. The points were chosen from preliminary analyses of the confluences of the tributaries of the Orós reservoir, thus making it possible to characterize their influence on the standards of water quality, and achieve a greater representativeness of the area and of human impact. The physical, chemical and biological analyses took place bimonthly, from April 2008 to March 2011, giving a total of 4,032 samples. To assess the impact of human activities and natural factors on water quality in the Orós reservoir, the following attributes were analysed: temperature, $\mathrm{pH}$, electrical conductivity (EC), turbidity, colour, Sechi transparency, total solids (TS), volatile solids (TVS) and fixed solids (TFS), total suspended solids (TSS), volatile suspended solids (VSS) and 
fixed suspended solids (FSS), total dissolved solids (TDS), dissolved oxygen $(\mathrm{DO})$, biochemical oxygen demand $\left(\mathrm{BO}_{5} \mathrm{D}\right)$, soluble orthophosphate, sulfate, chloride $\left(\mathrm{Cl}^{-}\right)$, potassium $\left(\mathrm{K}^{+}\right)$, sodium $\left(\mathrm{Na}^{+}\right)$, calcium $\left(\mathrm{Ca}^{+2}\right)$, magnesium $\left(\mathrm{Mg}^{+2}\right)$, bicarbonate $\left(\mathrm{HCO}_{3}{ }^{-}\right)$, Escherichia coli (EC), thermotolerant coliforms (TTC) total ammonia, total Kjeldahl nitrogen (TKN), nitrate and chlorophyll-a, total phosphorus and sodium adsorption ratio (SAR). Sampling, preservation and transportation of the water samples to the laboratory was conducted by the standard methods reported by APHA (2005).

Multivariate statistical methods for classification, modeling and interpretation of large data sets may allow the reduction of the data set, and analysis of this information may be helpful for water quality assessment. In the present study, statistical analysis of the water quality data set was performed using SPSS software, v. 16.0. Besides standard descriptive statistics, Principal Component Analysis (FA/PCA) and Cluster Analysis (CA) were also performed.

The values of the different variables were standardized prior to the multivariate analyses, due to problems of no commensurate units. Scale standardization tends to minimize the influence of the difference of variance in variables, eliminates the influence of different units of measurement and renders the data dimensionless (Hair Júnior et al., 2005). All variables were standardized to a zero mean $(\mu=0)$ and a unit variance $(\sigma=1)$ to avoid differing scales by application of the Eq. 1.

$$
Y_{i j}=\frac{X_{i j}-\bar{X}_{i}}{S_{i}}
$$

where:

$\mathrm{X}_{\mathrm{ij}}$ - indicates the original value of the measured parameter, $\mathrm{Y}_{\mathrm{ij}}$ the standardized value

$\mathrm{X}_{\mathrm{i}}$ - the average value of variable $\mathrm{i}, \mathrm{S}_{\mathrm{i}}$ the standard deviation of $\mathrm{i}$

Data consistency was measured by the Kayser Mayer Olkim method (KMO). Further details of this test can be found in Silveira \& Andrade (2002); Hair Júnior et al. (2005). The KMO is considered as excellent when greater than or equal to 0.90 ; adequate between 0.70 and 0.90 , admissible between 0.50 and 0.70 and unacceptable when less than 0.50 (Silveira \& Andrade, 2002).

The number of factors to be extracted was defined by the criterion of characteristic roots, eigenvalues, where only components with an eigenvalue greater than one are considered, that is, the factor should explain a variance superior to that presented by a single variable (Hair Júnior et al., 2005). In general, when the factor-weighting matrix has values very close together or close to the mean value, the identification of the most significant variables becomes a difficult procedure. To minimize this limitation, an orthogonal transformation employing the varimax algorithm was employed, since this has already been used by different researchers (Andrade et al., 2007; 2008; Lopes et al., 2009). In order to minimize the degree of difficulty in identifying the significant factors of the factor loadings matrix, the orthogonal transformation procedure, Varimax, or a simple rotation of the factor loadings matrix was used. Rotation of the matrix is intended to minimize the contribution of variables with lower significance on the factor (Hair Júnior et al., 2005).

Aiming to classify water quality into similar groups that express hydrochemical responses with similar trends, cluster analysis (CA) was used employing the agglomerative method, using the variables determined by principal component analysis. Similarity was estimated by use of the Euclidean distance squared. The clustering algorithm for defining the aggregates was the Ward method. When defining the optimal number of clusters, the "clustering coefficient" (CC), calculated by Eq. 2, was used, it being understood that sudden increases in the clustering coefficient represent the clustering of different elements: in a dendrogram, such increases are represented by the greatest values of the rescaled aggregate-clustering distance (Hair Júnior et al., 2005).

$$
C A=\sum_{j=1}^{k}\left[\sum_{i=1}^{n_{j}} X_{i j}^{2}-\frac{1}{n_{j}}\left(\sum_{i=1}^{n_{j}} X_{i j}\right)^{2}\right]
$$

where:

CA - coefficient of agglomeration

$\mathrm{X}_{\mathrm{ij}}$ - value of the individual sample $\mathrm{i}$ in each group $\mathrm{j}$

$k \quad$ - total number of samples at each stage

$n_{j} \quad$ - number of samples in the group

The average data for each parameter analyzed in the respective groups thus formed were analyzed by testing the mean, and compared by $t$ test at 0.01 significance.

\section{Results AND Discussion}

Although 32 variables were evaluated, the sensitivity test performed by the Factor Analysis/Principal Component Analysis model (FA/PCA) identified that only 14 of them had any significance in explaining the total variance of the data (Table 1). The Kaiser-Meyer-Olkin (KMO) sufficiency test showed an index equal to 0.60 , which is considered acceptable (Silveira \& Andrade, 2002), demonstrating that the model would promote significant reduction in the size of the original data (Hair Júnior et al., 2005). Andrade et al. (2007) studying the determining factors for the quality of the surface waters in the watershed of the Upper Acaraú in Ceará, found a similar $\mathrm{KMO}, 0.625$, also rated as acceptable.

The best-fit model according to KMO test was that composed of five components (Table 1).

It can be seen that the first five components accounted for $29.48,18.27,15.14,11.47$ and $10.02 \%$ respectively of the total variance of the data, concentrating in five dimensions $84.39 \%$ of the information previously dissolved in fourteen dimensions (Table 1). Similar results were found by Li et al. (2011) when identifying the natural and anthropogenic sources of the pollution of the surface waters of the Changjiang and Huaihe watersheds, on the Haihe and Yellow rivers, China, by the use 
Table 1. Matrix of factor loadings using the principalcomponent method of the waters of the Orós reservoir in Ceará

\begin{tabular}{|c|c|c|c|c|c|c|}
\hline \multirow{2}{*}{$\mathrm{Nbr}$} & \multirow{2}{*}{ Variables } & \multicolumn{5}{|c|}{ Factors } \\
\hline & & F1 & F2 & F3 & F4 & F5 \\
\hline 1 & SAR & 0.902 & 0.193 & 0.006 & -0.073 & -0.326 \\
\hline 2 & $\mathrm{~K}^{+}\left(\mathrm{mmol}_{\mathrm{c}} \mathrm{L}^{-1}\right)$ & 0.890 & 0.120 & 0.070 & -0.111 & -0.337 \\
\hline 3 & $\mathrm{Na}+\left(\mathrm{mmol}_{\mathrm{c}} \mathrm{L}^{-1}\right)$ & 0.881 & 0.150 & 0.216 & -0.175 & -0.319 \\
\hline 4 & $\mathrm{pH}$ & 0.803 & -0.167 & 0.028 & 0.160 & 0.385 \\
\hline 5 & Clorophyll-a $\left(\mu \mathrm{g} \mathrm{L}^{-1}\right)$ & 0.652 & -0.267 & 0.055 & 0.296 & 0.243 \\
\hline 6 & $\mathrm{DO}\left(\mathrm{mg} \mathrm{L}^{-1}\right)$ & 0.640 & -0.267 & -0.007 & 0.424 & 0.129 \\
\hline 7 & Apparent Colour (uH) & -0.119 & 0.943 & 0.033 & -0.027 & 0.186 \\
\hline 8 & Turbidity (UT) & 0.094 & 0.929 & -0.091 & -0.061 & 0.054 \\
\hline 9 & Transparency (m) & -0.327 & -0.652 & 0.132 & 0.027 & -0.413 \\
\hline 10 & $\mathrm{Mg}^{+2}\left(\mathrm{mmol}_{\mathrm{c}} \mathrm{L}^{-1}\right)$ & -0.068 & -0.050 & 0.787 & -0.495 & -0.029 \\
\hline 11 & $\mathrm{Ca}^{+2}\left(\mathrm{mmol}_{\mathrm{c}} \mathrm{L}^{-1}\right)$ & 0.023 & -0.118 & 0.773 & -0.453 & 0.159 \\
\hline 12 & TSS $\left(\mathrm{mg} \mathrm{L}^{-1}\right)$ & -0.233 & 0.222 & 0.648 & 0.597 & -0.101 \\
\hline 13 & FSS (mg L-1) & -0.201 & 0.231 & 0.582 & 0.670 & -0.175 \\
\hline \multirow[t]{4}{*}{14} & TKN $\left(\mathrm{mg} \mathrm{L}^{-1}\right)$ & 0.188 & -0.130 & 0.252 & -0.066 & 0.763 \\
\hline & Eigenvalue & 4.13 & 2.56 & 2.12 & 1.61 & 1.40 \\
\hline & Variance (\%) & 29.48 & 18.27 & 15.14 & 11.47 & 10.02 \\
\hline & Accumulated variance (\%) & 29.48 & 47.75 & 62.90 & 74.37 & 84.39 \\
\hline
\end{tabular}

of multivariate analysis, where they found a model consisting of five components (Table 1 ) and accounting for $83.35 \%$ of the total variance. Andrade et al. (2008) studying the water quality of the Trussu river located in the watershed of the Upper Jaguaribe in Ceará, found a model consisting of three components and accounting for $76.41 \%$ of the total variance for the surface waters.

The values of the factor loadings for the components (Table 1) express the relationship between factors and variables, and allow identification of those variables with a greater weighting for each component. The high values of the weighted factorials suggest the most significant variables for each factor in the explicability of the total variance.

In the first, $\mathrm{F} 1$, (Table 1) the variables $\mathrm{SAR}, \mathrm{K}^{+}$and $\mathrm{Na}^{+}$ presented weightings greater than 0.88 , indicating that these are the most significant in the $\mathrm{C} 1$ class. The second, F2, is mainly explained by the variables, apparent color and turbidity (weighting > 0.92). The $\mathrm{F} 3$ component presented the variables $\mathrm{Mg}^{+2}$ (magnesium) and $\mathrm{Ca}^{+2}$ (calcium) as the most significant, with a weighting of over 0.77 . Whereas F4 and F5 were made up from a single variable for each component, being FSS (weighting $=0.670$ ) and TKN (weighting $=0.763$ ).

In this study, the adoption of a matrix transformed by the varimax method (Table 2) generated significant changes in relation to the original matrix (Table 1). A better distribution of the total variance over the five components can be seen. Comparing Tables 1 and 2, a reduction in the percentage of the total variance can be seen, which is explained by VF1 (23.00\%) and VF2 (17.24\%), with a consequent increase in the percentage of variance, explained by VF3 (16, 94\%), VF4 (13.76\%) and VF5 (13.44\%), with there being no change in the total explained by the model (84.39\%). A better distribution of the total variance among the components by matrix rotation was also observed by Bouza-Deaño et al. (2008), Li et al. (2011), Zhang et al. (2011) and Guedes et al. (2012), in research into water quality.
Table 2. Matrix of factor loadings of the variables transformed using the varimax algorithm of the five main selected components in the water of the Orós reservoir

\begin{tabular}{|c|c|c|c|c|c|c|c|}
\hline \multirow{2}{*}{$\mathrm{Nbr}$} & \multirow{2}{*}{ Variables } & \multicolumn{5}{|c|}{ Components } & \multirow{2}{*}{$C^{*}$} \\
\hline & & VF1 & VF2 & VF3 & VF4 & VF5 & \\
\hline 1 & $\mathrm{Na}^{+}\left(\mathrm{mmol}_{\mathrm{c}} \mathrm{L}^{-1}\right)$ & 0.950 & 0.090 & 0.189 & 0.174 & -0.039 & 0.978 \\
\hline 2 & SAR & 0.946 & 0.134 & 0.200 & -0.056 & -0.08 & 0.962 \\
\hline 3 & $\mathrm{~K}^{+}\left(\mathrm{mmol}_{\mathrm{c}} \mathrm{L}^{-1}\right)$ & 0.942 & 0.060 & 0.199 & 0.020 & -0.08 & 938 \\
\hline 4 & Apparent Colour (uH) & -0.056 & 0.931 & -0.1 & 0.020 & 0.170 & 0.938 \\
\hline 5 & Turbidity (uT) & 0.178 & 0.899 & & -0.089 & 0.063 & 40 \\
\hline 6 & Transparency (cm) & -0.122 & -0.783 & -0.2 & 0.067 & 0.107 & 0.888 \\
\hline 7 & $\mathrm{pH}$ & 0.399 & 0.022 & 0.822 & -0.019 & -0.110 & 0.720 \\
\hline 8 & Cloro & 0.329 & -0.145 & 0.7 & -0.091 & 0.040 & \\
\hline 9 & TKN & -0.256 & 0.150 & 0.6 & 0.3 & -0.1 & 0.702 \\
\hline 10 & $\mathrm{DO}\left(\mathrm{mg} \mathrm{L}^{-1}\right)$ & 0.362 & -0.193 & 0.663 & -0.235 & 0.122 & 0.678 \\
\hline 11 & $\mathrm{Mg}^{+2}\left(\mathrm{mmol}_{\mathrm{c}} \mathrm{L}^{-1}\right)$ & 0.082 & -0.070 & -0.141 & 0.909 & 0.115 & 0.872 \\
\hline 12 & $\mathrm{Ca}^{+2}\left(\mathrm{mmol}_{\mathrm{c}} \mathrm{L}^{-1}\right)$ & 0.037 & -0.064 & 0.074 & 0.908 & 0.06 & 0.842 \\
\hline 13 & FSS ( & -0.048 & 0.043 & -0.0 & 0.030 & 0.95 & \\
\hline & TSS $\left(\mathrm{mg} \mathrm{L}^{-1}\right)$ & -0.102 & 0.060 & -0.007 & 0.139 & 0.925 & 0.890 \\
\hline & & 320 & 2.41 & 237 & 193 & & \\
\hline & Varian & 23.00 & 17.24 & 16.94 & 13.76 & 13.44 & \\
\hline & Accumulated variance (\% & 23.00 & 40.24 & 57.18 & 70.95 & 84.39 & \\
\hline
\end{tabular}

* $\mathrm{C}$ : Communality - when over 0.5 means that the corresponding factor reproduces more than half the variance of the corresponding variable

After rotation, VF1 expressed a strong association with the parameters $\mathrm{Na}^{+}(0.950)$, RAS (0.946) and $\mathrm{K}^{+}(0.942)$. Similar results were found by Andrade et al. (2007) and Palácio et al. (2011) in studies of surface water in the state of Ceará, where the $\mathrm{Na}^{+}$showed a high factor loading in the first component. The VF4 showed high positive coefficients for the elements $\mathrm{Mg}^{+2}$ (0.909) and $\mathrm{Ca}^{+2}$ (0.908). Both the components VF1 and VF4 are indicators of hydrochemical parameters (salts). It therefore becomes evident that they are connected with the natural geological weathering of the soil components (BrodnjakVoncina et al., 2002). Geologically the Upper Jaguaribe watershed consists of rocks with a Precambrian crystalline base (81.28\%), represented by various gneisses, migmatites, quartzites and metalimestones, associated with plutonic and meta-plutonic rocks, composed predominantly of granite (IPECE, 2010).

VF2 presents high positive coefficients for apparent color (0.931), turbidity (0.899), and a negative coefficient for transparency (-0.783). As for VF5 there are high factor loadings for the variables FSS and TSS (weightings greater than 0.92). The variables grouped by the components VF2 and VF5 represent a single "physical" factor expressing the influence of surface runoff in agricultural areas (7.25\%), exposed soil (1.24\%) and anthropogenic areas $(18.50 \%)$ of the total area of the Upper Jaguaribe watershed in Ceará (COGERH, 2011). In 31.9\% of the total area of the Upper Jaguaribe basin Neosol soil types predominate (IPECE, 2010).

VF3 had a greater weight for $\mathrm{pH}$, chlorophyll-a, TKN and DO respectively (Table 2), being a component which indicates organic pollution. This VF acted as a component indicative of anthropic action on water quality. The VF3 component suggests that agricultural and pastoral activities in the region, sources of diffuse pollution, together with the low percentage (11.22\%) of households connected to the domestic-sewage 
network in the basin of the Upper Jaguaribe (IPECE, 2010), influence the nutrient concentration of surface waters: nitrate and phosphorus, elements defined in the literature as indicators of agricultural activities (Andrade et al., 2007).

The similarity of the water collected at various points of the Orós reservoir in the Alto Jaguaribe watershed during the period monitored, was identified employing hierarchical cluster analysis of the variables that were significant in explaining the total variance of the data (Table 2). Defining the number of groups was based on the first major difference between the clustering coefficients of two consecutive groups (Table 3). In the dendrogram (Figure 2), which corresponds to the figure of rescaled clustering coefficients, where the smallest coefficient corresponds to 1 and the largest to 25 , it is clear that the optimum cutoff point is a distance-value of around 1.927. From this, there is a greater distance in the measurement of similarity for the subsequent formation of clusters. The number of groups defined in the study using cluster analysis (CA) depends on the greater or lesser degree of homogeneity which it is desired to impose upon the groups formed (Andrade et al., 2008).

The similarity of the waters of the Orós reservoir makes up three groups (Figure 2) each with a different water quality (Table 4). Group 1 was formed by the waters taken from points P4, P5, P6 and P7, Group 2 was composed of the waters taken from points $\mathrm{P} 1$ and $\mathrm{P} 3$, whereas Group 3 was composed solely by the waters from point P2, Figure 2.

Further checking of Figure 2 shows that the seven monitoring points may be reduced to three (Figure 3 ). Singh et al. (2004), monitoring eight points to assess the water quality of the Gomti river in northern India, found that those collection points could be reduced to three. Varol et al. (2012) studying the water quality from reservoirs of the Tigris River basin in Turkey, evaluating the similarities of the water using the hierarchical cluster analysis found that monitoring points could be reduced from ten to four.

Table 3. Variation in the grouping coefficient for hierarchical cluster analysis

\begin{tabular}{cccc}
\hline $\begin{array}{c}\text { Number of } \\
\text { clusters }\end{array}$ & Coefficients & $\begin{array}{c}\text { Difference between } \\
\text { coefficients }\end{array}$ & $\begin{array}{c}\text { Rescaled } \\
\text { distance }\end{array}$ \\
6 & 0,000 & 0,001 & 1,000 \\
5 & 0,001 & 0,007 & 1,036 \\
4 & 0,008 & 0,021 & 1,260 \\
3 & 0,030 & 0,168 & 1,927 \\
2 & 0,198 & 0,572 & 7,167 \\
1 & 0,770 & & 25,000 \\
\hline
\end{tabular}

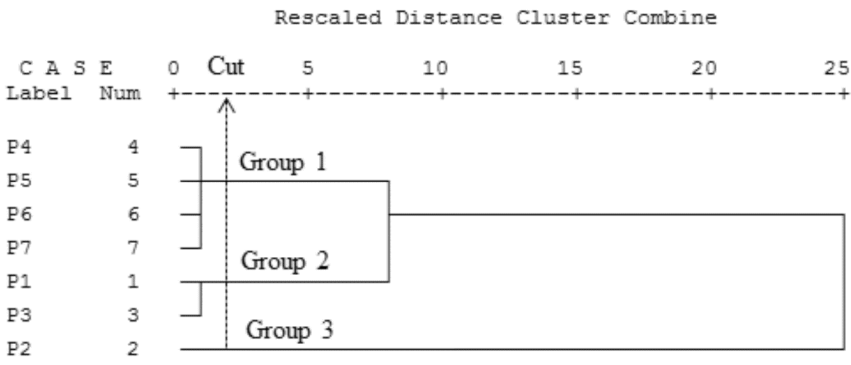

Figure 2. Dendrograms of clusters of the waters from the Orós reservoir

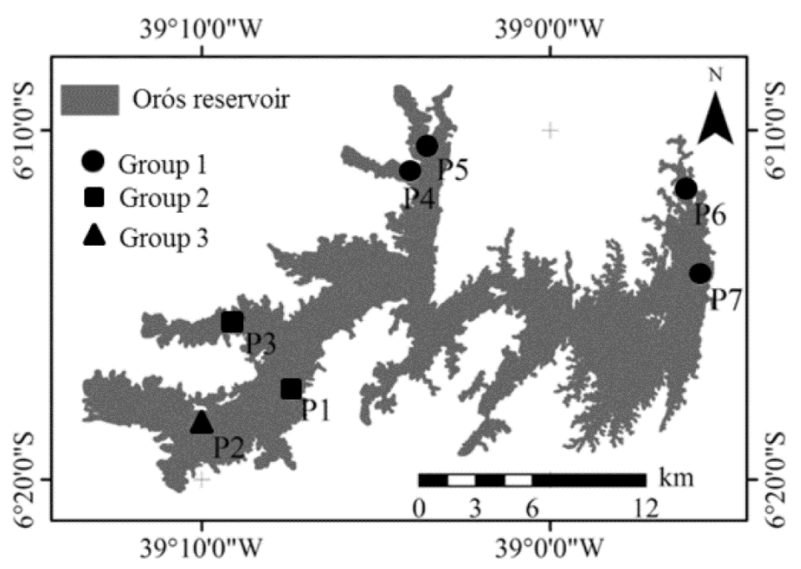

Figure 3. Cluster distribution in the Orós reservoir, Ceará

The determining attributes in the formation of Group 1 was turbidity $(5.78 \mathrm{uT})$, apparent colour $(32.34 \mathrm{uH})$ and transparency $(1.07 \mathrm{~m})$ which differed statistically from the $1 \%$ t-test level of the other groups. This is a group formed by those points that showed the highest values for transparency and lowest values for the attributes of turbidity and apparent colour (Table 4). However, the determining attributes of the dissimilarity of water quality of the points studied in the watershed of the Orós reservoir were the same. Soares et al. (2009) determining the classes of usage and occupation of land in the areas around the Orós reservoir, found that $32.98 \%$ of total usage is of natural pasture and land management, followed by the area occupied by poultry farming (15.68\%) and rice crops (11.17\%). Anthropic activities, a lack of sanitation, agriculture, solid waste, industry and many other activities pose risks to the water quality (Brasil, 2005).

For the remaining parameters, Group 1 was equal to Groups 2 and 3, except for $\mathrm{pH}$ (8.52), TSS (11.75 $\left.\mathrm{mg} \mathrm{L}^{-1}\right)$, FSS (5.26 mg $\left.\mathrm{L}^{-1}\right)$ that all differed from Group 3, and for which Group 1 had the lowest values of TSS and FSS and the highest values of $\mathrm{pH}$ and chlorophyll-a, where Group 1 had the highest concentration (20.04 $\mathrm{mg} \mathrm{L}^{-1}$ ) and differed statistically from Group 2.

The attributes determining the formation of Group 2 were turbidity $(15.62 \mathrm{uT})$, apparent color $(62.31 \mathrm{uH})$ and transparency $(0.63 \mathrm{~m})$, which were statistically different from the $1 \% \mathrm{t}$-test level of the other groups. This group showed intermediate mean values of the concentrations of the mentioned attributes (Table 4).

As for Group 3, the attributes that differed statistically from the $1 \%$ t-test level of the other groups were also turbidity, apparent colour and transparency, which showed higher values than in the other groups, except for transparency which had the lowest value (Table 4). It appears that the physical parameters were instrumental in the formation of the three groups. The physical attributes are an expression of the influence of surface runoff from the agricultural areas (7.25\%), areas of exposed soil (1.24\%) and anthropogenic areas (18.50\%) of the total area of the Upper Jaguaribe watershed in Ceará (COGERH, 2011). Soares et al. (2009) determining the classes of land usage and occupation in the areas around the Orós reservoir, found 
Table 4. Statistics of the variables for similar groups for the waters of the Orós reservoir, as determined by cluster analysis

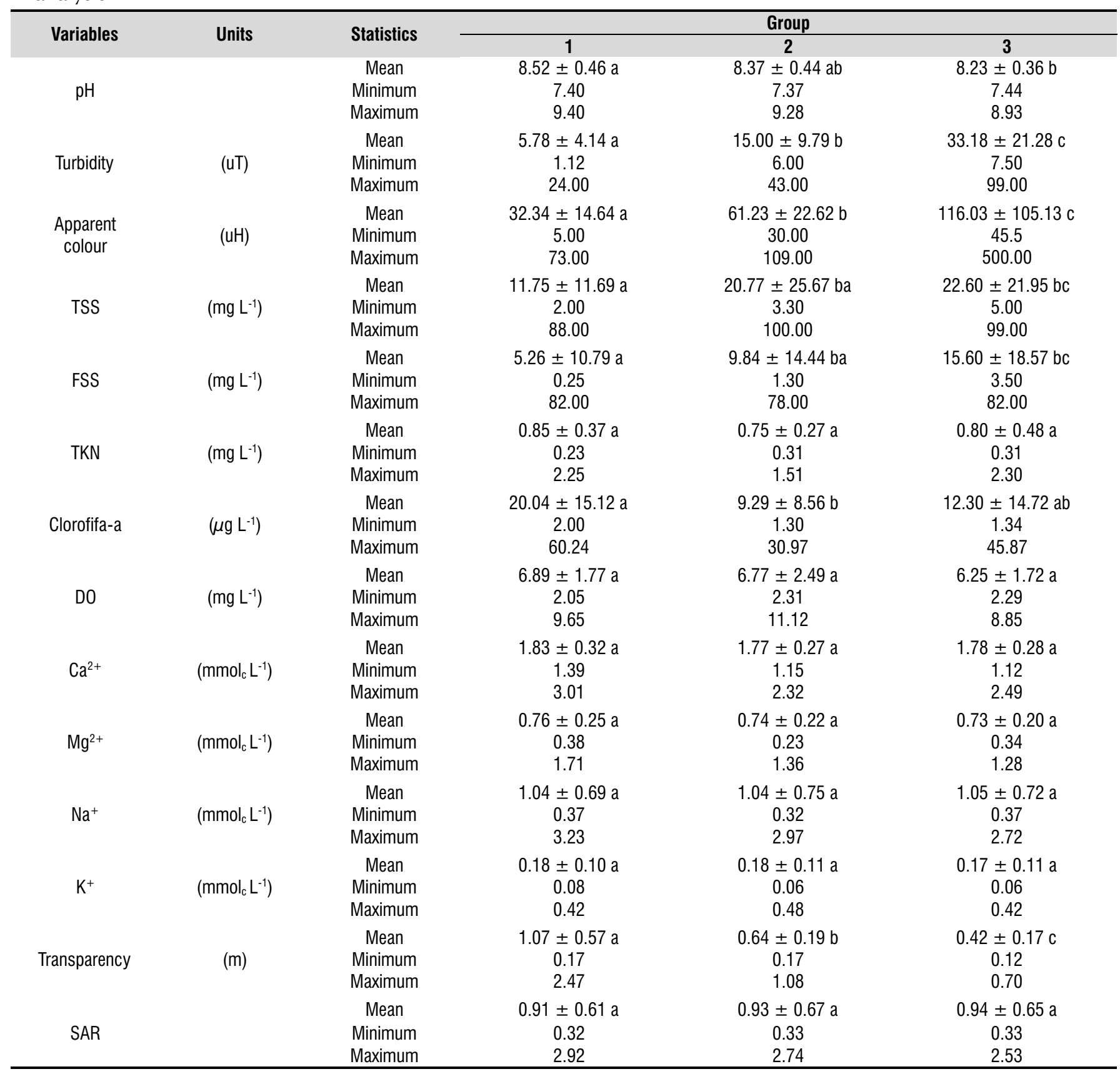

that $59.83 \%$ of the total usage had already undergone changes (natural pasture and land management, poultry farming and rice crops). The variability of the attributes determining water quality is defined by the natural conditions of climate, geomorphology and geochemistry of the environment as well as the usage and occupation of land (Fernandes et al., 2010).

Group 3 being formed solely from collection point 2, occurred because of it being the largest contributing tributary to the buildup of water in the Orós reservoir in Ceará. This underlines the importance of the Jaguaribe tributary as a contributing factor, since, according to Araújo (2003), the average loss of water volume stored in reservoirs in Ceará due to silting is $1.85 \%$ per decade. For Ceará, it is estimated that this loss is approximately $22 \mathrm{hm}^{3}$ per year.
The similarity of the waters has been influenced by anthropogenic activities carried out near the reservoir and along the basin. Tanriverdi \& Demirkiran (2010), found similar results when studying the quality of surface water in the watershed of the River Ceyhan in Turkey; applying cluster analysis, the waters of the river were divided into three groups which are influenced by human activity (industrial and agricultural).

The quality of the surface waters of the Orós reservoir for the parameters $\mathrm{pH}$, turbidity, dissolved oxygen - DO and chlorophyll-a was below the maximum limits established in Conama Resolution 357/2005, with usage compatible with that of freshwater from class 2 (Table 5), which is intended for the supply of water for human consumption after conventional treatment, the protection of aquatic communities, the recreation 
Table 5. Quality standards for Class 2 freshwater Conama Resolution 357/2005

\begin{tabular}{lc}
\hline \multicolumn{1}{c}{ Variables } & Class 2 limit \\
pH & 6.0 a 9.0 \\
Turbidity $(\mathrm{uT})$ & 100 \\
Clorophyll-a $\left(\mu \mathrm{g} \mathrm{L}^{-1}\right)$ & 30 \\
$\mathrm{D} 0\left(\mathrm{mg} \mathrm{L}^{-1}\right)$ & $\geq 5.0$ \\
\hline
\end{tabular}

Source: Brasil (2005)

of primary contact, fishing and the irrigation of vegetables and fruit that are eaten raw.

As to the eutrophication process, chlorophyll-a is considered to be a measure of the response of the body of water to the presence of total phosphorus, indicating the level of algae growth. In this way, the presence of phosphorus and chlorophyll act satisfactorily as, respectively, the cause and effect of the eutrophication process. The waters belonging to Groups 1 and 3 were classified as eutrophic (Table 6), while the waters of Group 2 (P1 and P3) were classified as mesotrophic. The eutrophic state for Group 1 (P4, P5, P6 and P7) and Group 3 (P2) is indicative of the inadequate occupation, use and management of the land around the reservoir and its contributing watershed. Soares et al. (2009) found that the Permanent Preservation Areas (PPA) are mainly occupied by pasture (42.38\%) and rice crops (15.83\%), with only $7.77 \%$ of the area having natural vegetation.

It is considered that in a body of water, where the eutrophication process is fully established, the trophic status, which is determined by the chlorophyll-a content, should match the trophic status determined by that of phosphorus. However, the concentration of chlorophyll-a does not only depend on the availability of total phosphorus but also on other nutrients and factors such as the amount of sunlight penetrating the water.

The surface waters of the Orós reservoir are classified as eutrophic (Table 6) by evaluation corresponding to the total phosphorus. Two of the main artificial sources of phosphorus are domestic sewage and agricultural fertilizers (Alexandre et al., 2010; Shrestha \& Kazama, 2007). In the areas of land usage and occupation around the Orós reservoir, 59.83\% of the total usage has already undergone change (natural pasture and land management, poultry farming and rice crops) (Soares et al., 2009 ), and only $11.22 \%$ of households are connected to the sewage network in the Upper Jaguaribe basin (IPECE, 2010).

Table 6. Classification criteria for eutrophication and the inclusion of similar groups as regards water quality

\begin{tabular}{|c|c|c|}
\hline $\begin{array}{c}\text { Trophic } \\
\text { categorias }\end{array}$ & $\begin{array}{l}\text { Clorophyll-a } \\
\left(\mu \mathrm{L} \mathrm{L}^{-1}\right)\end{array}$ & $\begin{array}{l}\text { Total phosphorous } \\
\text { (mg L-1) }\end{array}$ \\
\hline Oligotrophic & $\leq 4.8$ & $\leq 0.028$ \\
\hline Mesotrophic & $4.8-12$ & $0.028-0.072$ \\
\hline Eutrophic & $\geq 12$ & $\geq 0.072$ \\
\hline \multicolumn{3}{|c|}{ Group mean values } \\
\hline Group 1 & 20.04 & 0.10 \\
\hline Group 2 & 9.29 & 0.14 \\
\hline Group 3 & 12.30 & 0.16 \\
\hline \multicolumn{3}{|c|}{ Group eutrophication classification } \\
\hline Group 1 & Eutrophic & Eutrophic \\
\hline Group 2 & Mesotrophic & Eutrophic \\
\hline Group 3 & Eutrophic & Eutrophic \\
\hline
\end{tabular}

The main consequences in eutrophic aquatic systems are: anoxia (the absence of dissolved oxygen) which causes the death of fish and invertebrates, and also results in the release of toxic gases having unpleasant odours; algal blooms and the uncontrolled growth of other aquatic plants; the production of toxic substances by certain species of cyanobacteria; high concentrations of organic matter which, if treated with chlorine, can create carcinogenic compounds (Smith, 2003); deterioration of the recreational value of a lake or reservoir due to the reduction in water transparency; restricted access to fishing and recreational activities due to the accumulation of aquatic plants; fewer species of plants and animals (biodiversity); changes in the composition of species; and decreased fish production caused by oxygen depletion in the water column (Smith, 2003; Smith \& Schindler, 2009).

It can also be seen from Table 4 that the waters used in irrigated agriculture do not present a risk of sodium buildup since the mean SAR values are below the limit for this parameter that restrict the use of the waters for irrigation, i.e. 3.0 (Ayers \& Westcot, 1999). However when the SAR was evaluated in conjunction with the electrical conductivity of the water - CEa, Table 7, as proposed by Ayers \& Westcot (1999), it was found that the degree of restriction in usage, and the risk of their causing problems of infiltration is severe for groups 1 and 2 , with a SAR of between 0.0 and 3.0 and a CEa of less than $0.20 \mathrm{dS} \mathrm{m}^{-1}$, and is mild to moderate for group 3, with a SAR between 0.0 and 3.0 and CEa between 0.20 to $0.70 \mathrm{dS} \mathrm{m}^{-1}$ (Ayers \& Westcot, 1999). The problem of infiltration is caused by the leaching of clay at the deeper layers, causing a blockage of pores. For any given $\mathrm{SAR}$, infiltration generally increases with an increase in CEa and decreases with its reduction.

Table 7. Degrees of restriction on use for irrigation of the waters of the Orós reservoir in Ceará

\begin{tabular}{lcc}
\hline \multicolumn{1}{c}{ Groups } & SAR & CEa $\left(\mathbf{d S ~ m}^{-1}\right)$ \\
Group 1 & 0.91 & 0.185 \\
Group 2 & 0.93 & 0.194 \\
Group 3 & 0.94 & 0.210 \\
\hline Degree of restriction on use & \multicolumn{2}{c}{ Severe } \\
Group 1 & \multicolumn{2}{c}{ Severe } \\
Group 2 & \multicolumn{2}{c}{ Light to moderate } \\
Group 3 & \multicolumn{2}{c}{} \\
\hline
\end{tabular}

The quality of the water for use in irrigated agriculture showed no risk of generating salinity problems, $\mathrm{CEa}<0.700$ $\mathrm{dS} \mathrm{m} \mathrm{m}^{-1}$ or of toxicity of the sodium ion $\left(3.0 \mathrm{mmol}_{\mathrm{c}} \mathrm{L}^{-1}\right)$ (Ayers $\&$ Westcot, 1999).

The dynamics of sodium, calcium, magnesium and potassium (Table 4) in the surface waters of the Orós reservoir present low spatial variation; similar behaviour was found by (Meireles et al., 2007; Alexandre et al., 2010) in studies of the quality of surface water.

\section{Conclusions}

1. The majors factors responsible for water quality composition are: the natural weathering of geological soil 
components; the entrainment of suspended solids through surface runoff from agricultural areas; and anthropogenic action in the Upper Jaguaribe basin in Ceará.

2. In relation to spatial variability of water quality, the CA technique clustered three similar groups. The similarity of the water of the Orós reservoir allows a reduction in the number of sampling points, which may result in significant cost savings without sacrificing important water quality data.

3. The quality of the surface water in the reservoir for use in irrigated agriculture, regarding the risk of sodium buildup, is severe for groups 1 and 2, and mild to moderate for group 3. The water presents no risk of causing problems of salinity.

4. The dynamics of sodium, calcium, magnesium and potassium in the surface waters of the Orós reservoir present low spatial variation.

\section{ACKNOWLEDgements}

The authors thank CNPq, CAPES and INCTSal for the financial support given to this research, and for the doctor' student grant given to the first author.

\section{Literature Cited}

Alexandre, D. M. B.; Andrade, E. M.; Lopes, F. B.; Palácio, H. A. Q.; Ferreira, A. C. S. The water quality investigation using GIS and multivariable analysis in a semiarid region reservoir. Revista Ciência Agronômica, v.41, p.554-561. 2010.

Andrade, E. M.; Araújo, L. F. P.; Rosa, M. F.; Disney, A. Seleção os indicadores da qualidade das águas superficiais na bacia do Baixo Acaraú, Ceará, pelo emprego da analise multivariada. Engenharia Agrícola, v.27, p.683-690. 2007.

Andrade, E. M.; Palácio, H. A. Q.; Souza, I. H.; Leão, R. A. O.; Guerreiro, M. J. Land use effects in groundwater composition of an alluvial aquifer (Trussu River, Brazil) by multivariate techniques. Environmental Research, v.106, p.170-177. 2008.

APHA - American Public Health Association, AWWA American Water Works Association and WEF - Water Environment Federation, Standard methods for the examination of water and wastewater. 21.ed. Washington: American Public Health Association. 2005. 874p.

Araújo, J. C. Assoreamento em reservatórios do semiárido: Modelagem e validação. Revista Brasileira de Recursos Hídricos, v.8, p.39-56. 2003.

Ayers, R. S.; Westcot, D. W. A qualidade da água na agricultura. 2.ed. Campina Grande: UFPB, 1999. 153p. FAO, Irrigação e Drenagem, 29.

Bouza-Deaño, R.; Ternero-Rodríguez, M.; Fernández-Espinosa, A.J. Trend study and assessment of surface water quality in the Ebro River (Spain). Journal of Hydrology, v.361, p.227239. 2008.

Brasil. Ministério do Meio Ambiente. Resolução CONAMA No 357 de 17 de março de 2005. <http://www.mma.gov.br/ conama/res/res05 /res35705.pdf.> 10 Abr. 2011.
Brodnjak-Voncina, D.; Dobcnik, D.; Novic, M.; Zupan, J. Chemometrics characterisation of the quality of river water. Analytica Chimica Acta, v.462, p.87-100. 2002.

COGERH - Companhia de Gestão dos Recursos Hídricos. Estudos ambientais. <http://portal.cogerh.com.br/eixosde-atuacao/estudos-e-projetos/planos-de-bacias/planode-gerenciamento-da-bacia-do-rio-jaguaribe/fase-idiagnostico $>27$ Mar. 2011.

Fernandes, F. B. P.; Andrade, E. M.; Fontenele, S. B.; Meireles, A. C. M.; Ribeiro, J. A. Análise de agrupamento como suporte à gestão qualitativa da água subterrânea no semiárido cearense. Revista Agro@mbiente, v.4, p.86-95. 2010.

Ferreira, M. O.; Ramos, L. M.; Rosa, A. L. T.; Lima, P. V. P. S.; Leite, L. A. S. Especialização produtiva e mudança estrutural da agropecuária cearense. Revista Teoria e Evidência Econômica, v.14, p.91-111. 2006.

Guedes, H. A. S.; Silva, D. D.; Elesbon, A. A. A.; Ribeiro, B. M.; Matos, A. T.; Soares, J. H. P. Aplicação da análise estatística multivariada no estudo da qualidade da água do Rio Pomba, MG. Revista Brasileira de Engenharia Agrícola e Ambiental, v.16, p.558-563. 2012

Hair Júnior, J. F.; Anderson, R. E.; Tathan, R. L.; Black, W. C. Análise multivariada de dados. 5.ed. Porto Alegre: Bookman, 2005. 593p.

IPECE - Instituto de Pesquisa e Estratégia Econômica do Ceará. Anuário Estatístico do Ceará 2010. <http://www2.ipece. ce.gov.br/publicacoes/anuario/ anuario2010/index.htm>. 27 Mar. 2011.

$\mathrm{Li}, \mathrm{S}$.; Li, J.; Zhang, Q. Water quality assessment in the rivers along the water conveyance system of the Middle Route of the South to North Water Transfer Project (China) using multivariate statistical techniques and receptor modeling. Journal of Hazardous Materials, v.195, p.306-317. 2011.

Lopes, F. B.; Andrade, E. M.; Aquino, D. N.; Lopes, J. F. B. Proposta de um índice de sustentabilidade do Perímetro Irrigado Baixo Acaraú, Ceará, Brasil. Revista Ciência Agronômica, v.40, p.185-193. 2009.

Meireles, A. C. M.; Frischkorn, H.; Andrade, E. M. Sazonalidade da qualidade das águas do açude Edson Queiroz, Bacia do Acaraú, no semiárido cearense. Revista Ciência Agronômica, v.38, p.25-31. 2007.

Palácio, H. A. Q.; Araújo Neto, J. R.; Meireles, A. C. M.; Andrade, E. M.; Santos, J. C. N.; Chaves, L. C. G. Similaridade e fatores determinantes na salinidade das águas superficiais do Ceará, por técnicas multivariadas. Revista Brasileira de Engenharia Agrícola e Ambiental, v.15, p.395-402. 2011.

Salas, H.; Martino, P. Metodologias simplificadas para la Evaluación de Eutroficación em Lagos Cálidos Tropicales. LIMA: Programa Regional CEPIS/HPE/IOPS, 2001. 52p.

Shrestha, S.; Kazama F. Assessment of surface water quality using multivariate statistical techniques: A case study of the Fuji river basin, Japan. Environmental Modelling \& Software, v.22, p.464-475, 2007.

Silveira, S. S.; Andrade, E. M. Análise de componentes principais na investigação da estrutura multivariada da evapotranspiração Revista Engenharia Agrícola, v.22, p.174$177,2002$. 
Singh, K. P.; Malika, A.; Mohana, D.; Sinhab, S. Multivariate statistical techniques for the evaluation of spatial and temporal variations in water quality of Gomti River (Índia) - A case study. Water Research, v.38, p.3980-3992. 2004.

Smith, V. H. Eutrophication of freshwater and coastal marine ecosystems. A global problem. Environmental Science and Pollution Research, v.10, p.126-139. 2003.

Smith, V. H.; Schindler, D. W. Eutrophication science: where do we go from here?. Trends in Ecology and Evolution, v.24, p.201-207. 2009.

Soares, Z. M. L.; Carvalho, M. S. B. S.; Soares, A. M. L.; Carvalho, G. M. B. S.; Almeida, M. A. G.; Santos, S. M.; Oliveira, F. A. J.; Chaves, L. C. G.; Freitas, H. C. Uso e ocupação da terra nas áreas de entorno do açude Orós com vistas ao ordenamento territorial. In: Simpósio Brasileiro de Sensoriamento Remoto, 14, 2009, Natal. Anais...Natal: INPE, 2009. p.4417-4424.
Tanriverdi, C.; Demirkiran, A. R. Assessment of surface water quality of the Ceyhan River basin, Turkey. Environmental Monitoring and Assessment, v.167, p.175-184. 2010.

UNESCO - Organização das Nações Unidas para a Educação, a Ciência e a Cultura. Relatório Mundial das Nações Unidas Sobre o Desenvolvimento dos Recursos Hídricos 4. <http:// unesdoc.unesco.org/images/0021/002154/ 215491por.pdf> . 10 Out. 2012.

Varol, M.; Gökot, B.; Bekleyen, A.; Şen, B. Spatial and temporal variations in surface water quality of the dam reservoirs in the Tigris River basin, Turkey. Catena, v.92, p.11-21. 2012.

Zhang, X.; Wang, Q.; Liu, Y.; Wu, J.; Yu, M. Application of multivariate statistical techniques in the assessment of water quality in the Southwest New Territories and Kowloon, Hong Kong. Environmental Monitoring and Assessment, v.137, p.17-27. 2011. 